\title{
Small and Medium Enterprises in Algeria after the corona crises -a forward looking vision for a better economic future -
}

\author{
Zina BENOUSSAD ${ }^{1}$ \\ ${ }^{1}$ PHD, Department of economics, Ahmed Draya ADRAR University, ALGERIA
}

\begin{abstract}
Aims: This study aims to address the opportunities available for the future sustainability of small and medium enterprises in Algeria after the Corona crisis, which was a strong shock that greatly affected the economy in general and its small and medium enterprises in particular.

Study design: The study was divided into two axes, the first concerned with the theoretical framework of small and medium enterprises and their importance, as well as the Corona virus and its reality in Algeria, while the second axis was devoted to studying the negative effects of each of the Corona virus and the precautionary measures applied to reduce it on the economy, small and medium enterprises, as well as the various opportunities available from this crisis to ensure an economy Better with more flexible and efficient SMEs.

Results: Among the most important results reached through this study is that the CORONAVIRUS has not only negative effects on Small and Medium Enterprises, but there are many positive effects that were represented in activation of electronic commerce, teleworking, electronic payment, and encouraging industrial diversity in small and medium enterprises, and adopting The concept of social responsibility by this enterprises.
\end{abstract}

Conclusion: as a conclusion of the study, it can be said that Algeria in the post-corona phase focuses on the aforementioned positive results and supports them, it will be able to turn the balance of Algerian economy for the better.

Key words: Coronavirus, the economy, small and medium enterprises, teleworking, distance education.

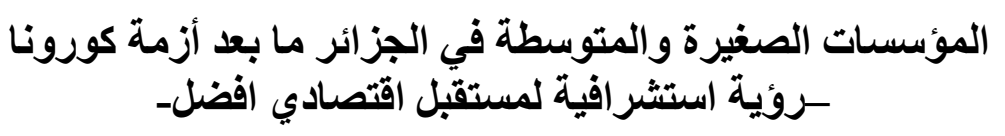

$$
\text { بن وستاذة زحاضرة بـ ب بسم العلوم الاقتصادية، جامعة أحمد دراية. أدرار، الجزائر }
$$

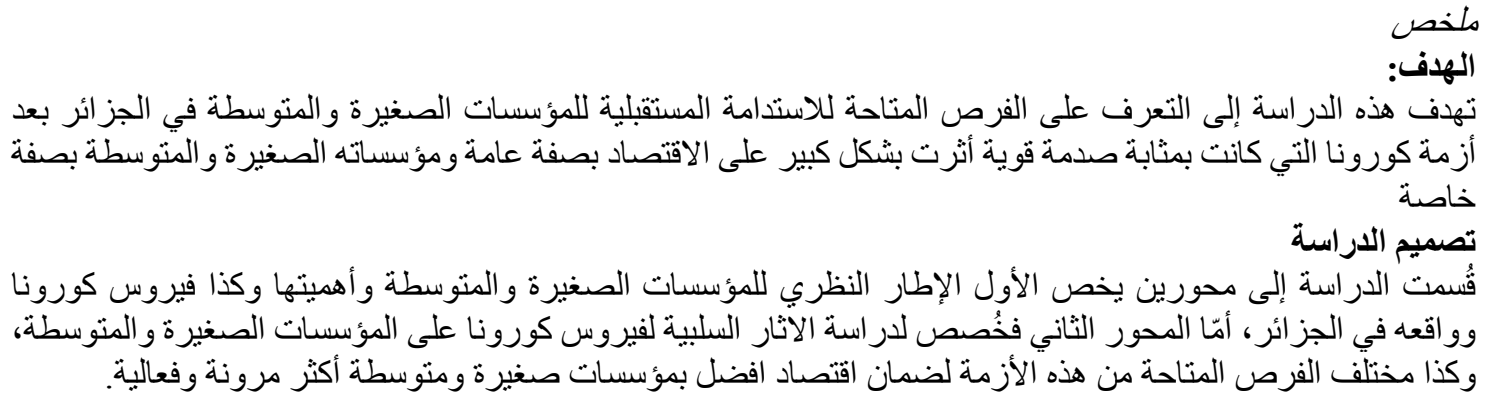


النتائج

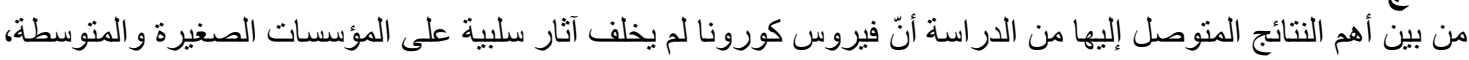

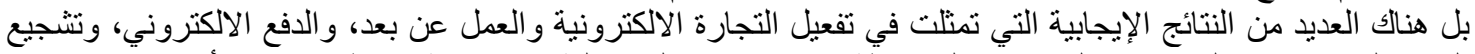

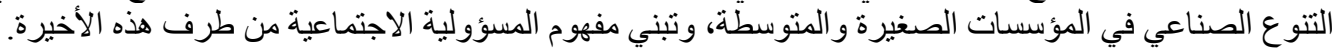

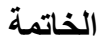

كخاتمة للار اسة يمكن القول أنّه إذا ركزت الجزائر في مرحلة ما بعد الكورونا على النتائج الإيجابية السابقة الذكر ودعمنها

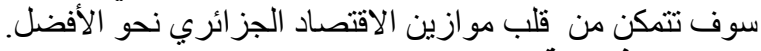
الكلمات الافتتاحية فيروس كورونا، الاقتصاد، المؤسسات الصغيرة و المتوسطة، العمل عن بعد، التعليم عن بعد.

التبـاعـد الاجتمـاعي، كـالحجر المنزلي الكلي والجزئي، الحجر الصــــي للمصـــابين، التوقيف الجزئي الكلي أو

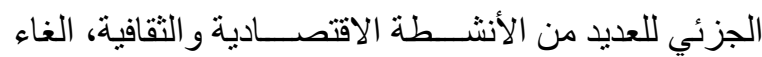
الرحلات البريـة و الجويـة والبحريـة بين الدول و الو لايـات وحتى البلديات أو المقاطعات. لقد كان للإجر اءات السابقة الذكر تأثنير إيجابي على الجانب الصــي للثـعوب حيث عرفت العديد من الدول انخفاضـا ملحوظا في عدد الإصـــابات و الوفيات، إلاّ أنّ تأثيره على الجانب الاقتصــادي و الاجتماعي كان ســلبيا، حيث كانت المؤسسات الصغيرة و المتوسطة من بين أكبر المتضررين من الجـائحسة في حـد ذاتهـا، ومن الإجر اءات الاحتر ازيـة المطبقة للحد منها، نتيجة توقف نشــاط الأغلبية منها جزئيا تبعـا لقرارات حكو ميـة مؤقتـة، أو كليـا نتيجـة عدم قدرتهـا على الصــمود في وجه الازمة، و هو ما نتج عنه تســريح للعمال وارتفاع البطالة و انخفاض القدرة الثـر ائية وارتفاع الأسـعار وبالتالي ارتفاع التضـخم ونسـبة الفقر إلى غير ها من العو اقب التي مسـت كل مجالات الحياة وقلبت الموازين الاقتصادية رأسا على عقب. رغم أنّ الآثار الســلبية لفيروس كورونـا مسّـــــ كل دول العالم دون اسـتثناء إلاّ أنّ انعكاسـهـ على اقتصــاديات الدول النامية التي تعتمد بشكل كبير على مداخيل النفط في تمويل مشـاريعها التنموية كان مضـاعفا، الثـيء الذي لمسناه فعليا في الجزائر كونها جزء لا يتجزأ من هذه الدول، فبالرغم

\section{1 (المقدمة}

شــــدت نهاية ســنة 2019 ظهور فيروس من فصــيلة الفيروســات التاجية، أطلق عليه تســية فيروس كورونا، و الذي يسبب حالات عدوى الجهاز التنفسي التي تتر اوح ما

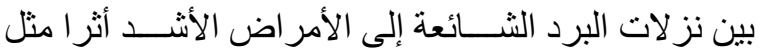

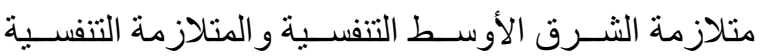
الحسادة (الســـارس)، حيث كان أوّل ظهور لـه في مدينـة ووهان الصينية، لينتشر بشكل سريع في كلّ أنحاء العالم، إذ تم الإعلان من طرف منظمة الصحة العالمية رسميا في 30 يناير 2020 بأنّ تفتــي الفيروس يشــــل حالة طو ارئ صحية عامة تبعث على القلق الدولي، وأكدت تحول الفاثية إلى جائحة يوم 11 مارس من نفس السنة.

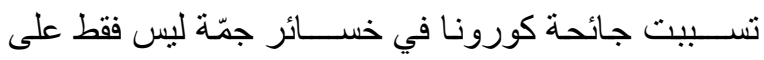
الصـعيد الصـحي، و إنّما على جميع الأصسعدة الاقتصـادية و الاجتمـاعية، فبالإضــــافـة إلى الارتفاع الهائل في عدد الإصـــابـات و عدد الموتى يوميـا جر اء هذا الوبـاء عرف لهف الاقتصـاد نو عا من الكسـاد وسـاءت الحالة المادية للعديد من فئات المجتمع و ارتفعت نســـبة البطالة و التضــــم في كلّ أنحاء العالم بنسب متفاوتة حسب الحالة الوبائية لكل دولة. ســت الدول في ظل هذه الازمـة إلى البحث عن حلول تسمح لها بالحد من انتشـار الوباء في وقت لا يتوفر فيه بعد اللقاح اللازم لوقف الجائحة، فاتُخذت العديد من التدابير و الإجراءات الاحتر ازيـة والتي ترمي في مجمها إلى مبدأ 


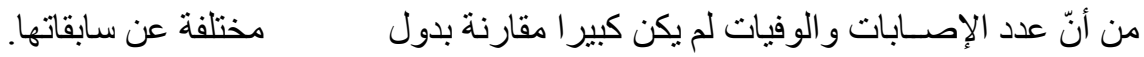

$$
\begin{aligned}
& \text { أخرى كالصـين و الو لايات المتحدة الامريكية، و إيطاليا، إلاّ الإل }
\end{aligned}
$$

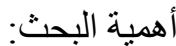

$$
\begin{aligned}
& \text { تبرز أهمية البحث من خلال ما يلي: } \\
& \text { أنّ العو اقب الاقتصادية والاجتماعية كانت وخيمة. } \\
& \text { 6. مشكلة الدراسة }
\end{aligned}
$$$$
\text { - ضـــامة الآثار الســلبية التي أســفرت عن فيروس }
$$$$
\text { كورونـا على جميع الأصـــعدة الصــــية و الاقتصــــادية }
$$$$
\text { و الاجتمـاعيـة في كلّ دول العـالم بصـــفة عـامـة و الجز ائر }
$$

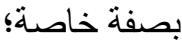$$
\text { - ضــرورة التفكير على المدى القريب و البعيد في وضــع }
$$$$
\text { اسـتر اتيجيات فعالة نابعة من الدروس المستمدة من الأزمة }
$$$$
\text { لتصحيح أخطاء الماضي و النهوض باقتصاد جزائري جديد }
$$

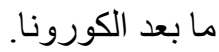

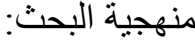

تم الاعتماد على المنهج الوصـفي التحليلي الذي يعتمد على تحليل النصـــوص ووصــف المعطيات و الاســتشـــــهاد بالإحصـــائيات و البيانات المأخوذة من المنظمات العالمية

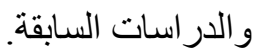

هيكلة الدر استة:

للوصــــ إلى الأهداف المنشـــودة تم تقسـيم الدر اســـة إلى عنصرين، تطرقنا في الأول منهم إلى التعريف بالمؤسسات الصـــيرة و المتوســــة في الجز ائر و أهم خصــــائصــــها و أهميتها في الاقتصـــاد الجزائري، وكذا فيروس كورونـا وو اقعه في الجزائر، أمّا الثاني فخصـصـناه لعرض مختلف الف الإجراءات الاحتر ازية التي وضـــــتها الحكومة الجز ائرية للتحكم في الفيروس و الحد من انتشـاره، وكذا مختلف الاثار الســلبية التي نتجبت عن ذلك، مع عرض نقاط القوة التي

$$
\text { يمكن الخروج بها من هذه الأزمة. }
$$

7.
نتيجة لماســبق أصــبح لز اما على الدولة الجز ائرية العمل على إيجاد حل مزدوج ومتتـاقض في نفس الوقت و الذي ينمثنل في ضـــرورة فرض الإجر اءات الوقائيسة للحد من انتثـار الوباء و التحكم فيه من جهة، وضـرورة التفكير في سُـبل للتخفيف من حدّة الأزمة و النهوض بالاقتصــاد عامة وبالمؤسســات الصـغيرة و المتوسطة خاصـة، و البحث عن استر اتيجيات جديدة مختلفة عمّا قبلها لاقتصساد جديد ما بعد الكورونا، من جهة أخرى. انطلاقا ممّا سبق يمكننا طر ح الإشكالية النالية: ما هي الفرص المتاحة أمام الجزائر للنهوض بالاقتصـــاد ويالمؤسسات الصغيرة والمتوسطة بعد أزمة كورونا؟ ويندرج في ظل هذا التسـاؤل مجمو عة من الأسـئلة الفرعية

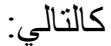
مــا هي مختلف التـدابير والإجراءات الاحترازيـة التي فرضنها الجزائر للحد من انتشار الوباء؟ كيف كان تأثير الفيروس على الاقتصـــاد الجزائري عامـة و على المؤسسات الصغيرة و المتوسطة خاصة؛ ما هي النقاط الاســتر اتيجية التي لا بد من الارتكاز عليها لخلق اقتصاد أفضل ما بعد الكورونا؟

$$
\text { أهداف البحث: }
$$

تهدف الدر اسـة إلى التعرف على الآثار السلبية التي انجرت عن انتشـــار فيروس كورونا في الجزائر على الاقتصـــاد و على المؤســــات الصــغيرة و المتوســة، و اســتخلاص النتائج الإيجابية التي أســفرت عن الأزمة و التي لا بد من الارتكاز عليها ودعمها لترميم الوضع الاقتصادي من جديد و النهوض بـه من خلال تبني اســـتر اتيجيـات جديدة فعالة 
تنافسية تعتمد على المواءمة بين استر اتيجية خفض الكلفة و استر اتيجية تميّز السلعة. دراســـة بن عديدة نبيل (بن عديدة ، 2020) بعنوان: " انعكـاســـات جـائحسة كورونـا (كوفيد 19) على نشــــاط المؤسـســات الصــيرة والمتوســة في الجزائر " و التي هدفت إلى التعرف على انعكاســـات جائحـــة كورونـا على لـ أداء ونثـــــاط المؤسســـات الصغيــــرة و المتوسطــــة في

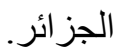

خلصت الدراسـة إلى نتيجة مفادها أنّ المؤسسـات الصغيرة و المتوسـطة تعتبر من بين أكثر القطاعات تضـررا بجائحة كورونـا وذللك نظر المحدوديـة مواردهـا المـاليـة من جهة ولتر اجع عـائدات النفط من جهـة أخرى، وأنّ اســتمرار الازمـة لفترة أطول ســـــف يفاقم من افلاس هذا النوع من المؤسسات ويرفع من نسبة البطالة. الفرق بين الدراســات السـابقة والدراسـة الحالية: تنتـابه در اسـتنا الحالية مع الدر اسـات السـابقة كونها تدرس تأثثير جائحة كورونا على المؤسسات الصغيرة و المتوسطة، وأنّ هذا القطاع كان الأكثر تضـــررا من الأزمة نفســـها ومن الإجر اءات الاحتر ازية المطبقة للحد من انتشــار الوباء، إلاّ أنّ در استتا الحالية تختلف عن الدر اسـات السـابقة فيما يتعلق بالنظرة الإيجابية التي تحملها هذه الدراسـة حول تأثثير أزمة كورونا على مستقبل الاقتصـاد بصفة عامة و المؤسسـات الصـغيرة و المتوسطة بصـفة خاصـة، و المتمثلة أسـاسـا في ادر الك هذا النوع من المؤسســات للعديد من الاسـتر اتيجيات و المبادئ التي تســمح لها بالاسـتمر ار و الصــمود في وجها الازمـات في المســتقبـل كـالتنوع الاقتصــــادي، التجـارة الالكترونيـة، التعليم عن بعـد، تفعيـل ســـــاســــة الـدفع الالكتروني، تبني سياسة المسؤولية الاجتماعية وغير ها من العو امل التي كانت غائبة بعض الثــيء في الو اقع الميداني لماقتصاد الجزائري.
دراسـة قيرواني لياس (KIROUANI, 2020) بعنو ان: " la pandémie de COVID-19 et les pme" و التي هدفت إلى تسـليط الضــوء حول تأثير أزمة كورونا على النشـاط اليومي للمؤسـســات الصـــيرة و المتوســـة الناثــطة في منطقة بجاية بالجز ائر، حيث مســت الدر اسـة عبنة مقدرة ب 32 مؤسسة. خلصت الدر اسة إلى أنّه كان لأزمة كورونا تأثنير كبير على ملى هذا النوع من المؤسسـات حيث شهدت العديد منها (خاصـة تلكلك التي تعدـل في القطـاعـات التي تمّ توقيفهـا كـاجر اء احتر ازي للحد من الوبـاء كـالنقل و المطاعم و المقاهي...) انخفاض كبير في رأس المال، إضــــافة إلى مو اجهتها لعدة صسوبات نتيجة للحجر المنزلي وتوقف حركة النقل تمثلت في انخفاض حجم العمالة بها، وبالتالي انخفاض انتاجها ومردوديتها، وارتفاع حاجاتها نحو التمويل الخارجي دراسـة ليراري ليلى، حمداوي وسـيلة \& LERARI

HAMDAOUI, 2020)

بـ "management pour les PME algériennes هدفت الدر اســة إلى التركيز على أهمية انتهاج المؤسـسـات الصـغيرة و المتوسطة استر اتيجية تمكنها من التنبؤ و التأقلم مع التحولات المســتقبلية، من خلال تبنيها لتقنيات إدارية حديثة مناسبة لذلك.

مست الدر اسـة المؤسسـات الصغيرة و المتوسطة الناشطة في و لابة ورقلة بالجزائر، حيث تمثلت نتائج الار اســـة في أن أزمة كورونا أثرت بثكل مباثر وكبير على المؤسسات الصـغيرة و المتوسطة محل الدر اسـة وخاصـة تللك الناشطة في قطاع التجارة، النقل، السـياحة، الفلاحة، وأصـبح من الضـــروري على هذا النوع من المؤســســـــات من تبنى اســتر اتيجية عامة تتمثل في التنوع الاقتصــادي، و التكامل المؤسساتي، واستعمال تكنولوجيا المعلومات، و استر اتيجية 
حيث يقصد في ظل هذا القانون بالمصطلحات التالية: الأشخاص المستخدمون: عدد الأشخاص الموافق لعدد وحدات العمل السنوية، بمعنى عدد العاملين الأجر اء بصفة

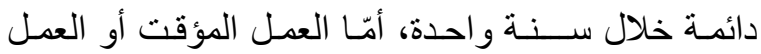
الموسمي فيعتبران أجز اء من وحدات العمل السنوي، إذ أنّ السنة التي يعتمد عليها هي تلك المتعلقة بآخر نشاط حسابي

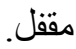

> الحـدود المعتبرة لتحـديـد رقم الأعمـال أو مجموع الحصــيلة: هي تلك المتعلقة بأخر نشـــاط مقفل مدة اثني

$$
\text { عشرة (12) شهر ا. }
$$

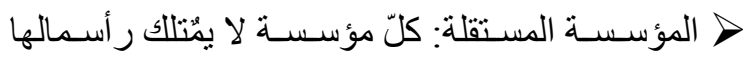

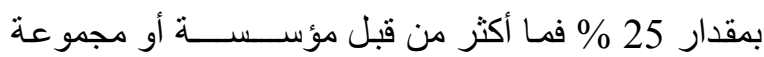
مؤسـســات أخرى لا ينطبق عليها تعريف المؤسـســات الصغيرة و المتوسطة.

كما تم التفريق في هذا القانون ما بين المؤسسات المتوسطة

$$
\text { و الصغيرة المصغرة كالتالي: }
$$

> المادة الخامسـة: عرّفت المؤسســـة المتوســة بأنّها مؤسـســة تثــلـ ما بين 50 إلى 250 عاملا ويكون رقم أعمالها ما بين مئتي (200) مليون وملياري (2) دج أو أن تكون مجموع حصـيلتها الســنوية ما بين مائة (100)

$$
\text { وخمسمائة (500) مليون دج. }
$$

لا المادة الســادسـة: عرّفت المؤسـســة الصــيرة بأنّها مؤسسة تشغل ما بين 10 إلى 49 شخصا ولا يتجاوز رقم أعمالها الســنوي مائتي (200) مليون دج أو لا يتجاوز مجموع حصيلتها السنوية مائة (100) مليون دج. > المادة السـابعة: عرّفت المؤسـســة المصـغرة بأنّها كلّ مؤسســـة تشــل من عامل إلى تسـعة عمال وتحقق رقم أعمال أقل من عثــرين (20) مليون دج أو لا يتجاوز مجموع حصيلتها السنوية عشرة (10) ملايين دج. خصائص المؤسسات الصغيرة والمتوسطة: أثبتت المؤسسـات الصغيرة و المتوسطة أهميتها في كلّ دول

\section{8.}

4 ـ. 1. مفاهيم عامة حول المؤسسات الصغيرة والمتوسطة وفيروس كورونا.

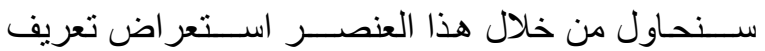
المؤسسات الصغيرة و المتوسطة حسب التشريع الجزائري، مع نوضـيح تقسـيم هذه المؤسـســات عبر مختلف قطاعات النشــاط، وكذا الخصـائص التي تتميّز بها، إضــافة إلى القاء نظرة حول معنى فيروس كورونا وو اقعه في الجز ائر.

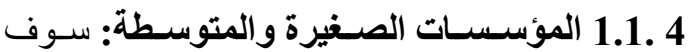
نتطرق من خلال هذا العنصر إلى التعرف على المؤسسات الصـغيرة و المتوسطة في القانون الجزائري، والخصـائص التي تميزهـا عن تلك الكبيرة والتي جعلت منهـا محركـا للاقتصـــاد، وكذا بعض الاحصـــائيات عن و اقعها ومدى أهميتها في الجز ائر.

\section{تعريف المؤسسات الصغيرة والمتوسطة:}

إنّ إيجاد تعريف موحد للمؤسسة الصغيرة و المتوسطة ييقى

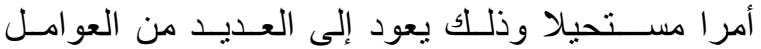
الاقتصـادية، التقنية والسياسية، كما أنّ تعاريفها تستتد إلى لى العديد من المعايير التي تختلف من دولة لأخرى ومن نشاط لأخر ومن صـناعة لأخرى، ولذلك سـوف نقتصـر فيما يلي على التعريف القانوني لهذا النوع من المؤســـــــات في لي

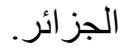
كانت أوّل محاولة رســية لتعريف المؤسـســات الصـغيرة و المتوســـة في الجزائر ضــــن القانون التوجيهي لترقية المؤسسـات الصـغيرة والمتوسطة رقم 18/01 المؤرخ في 12 ديسمبر 2001، والذي عرّفها حسب المادة الر ابعة منه بأنّها: "مؤسســة إنتاج السـلع و /أو الخدمات التي تشـخل من 1 إلى 250 شـــص، لا يتجاوز رقم أعمالها الســنـوي ملياري (2) دج أو لا يتجاوز مجموع حصـيلتها الســوية خمســمائة (500) مليون دج، بحيث يجب أن تســنتوفي معايير الاستقلالية. (الجريدة الرسمية العدد 77، 2001) 
1.193 .339 مؤسـســـة، بنســبة ارتفاع تقدر ب 4.5 \%

مقارنة بســة 2018، حيث تسـتحود المؤسـسـات الخاصـة

على نسبة 99.98 \%من مجموع المؤسسات، 56.25 \% منها تمثل مؤسسات أثخاص معنوية، أمّا 43.73 \% منها فهي مؤسـســات ذات طابع أثــخاص طبيعية، و لا تثــكل المؤســـــات العامة ســوى نسـبة 0.02 \% من مجموع

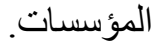

أمّا فيما يتعلق بتوزيع المؤسـســات الصــيرة و المتوســـة حسب قطاعات النشـاط، فبالنسـبة للمؤسـســات أنثـخاص معنوية يحتل قطاع الخدمات المرتبة الأولى بنسـبة 54.67 \%، يليه قطاع البناء و التهيئة العمر انية بنسبة 28.32 \% ثم قطاع الصـــناعات المصـــنعة بنســـبة 15.44 \%، أمّا قطاعي الزراعة والمحروقات فيحتلان اخر مرتبة بنســبة

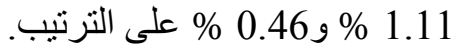
شَّل كبر مسـاحة الجز ائر وتنوع اقاليمها أحد أهم العناصـر المســـاهمة في تذبذب توزيع المؤســــــــات الصــــيرة و المتوســة حيث نجدها تتركز في منطقة الثـــال بنسـبة 69.59 \%، وتتضـــن منطقة الهضــاب العليا 21.98 \% منها، أمّا منطقة الجنوب فلا ينشـط بها سـوى 8.43 \% من مجموع المؤسسات. تؤُثر المؤسســات الصـغيرة و المتوسطة بشـكل إيجابي على العديد من المؤشرات الاقتصادية كما هو موضح فيما يلي: امتصاص البطالة: ساهمت المؤسسات الصغيرة و المتوسطة بشـــكل فعال في الحد من البطالة، حيث بلغ معدل العمالة سنة 2019 إلى 2.885 .651 عامل، بنسبة ارتفاع تقدر ب 5.92 \% مقارنة بسنة 2018، حيث يعتبر قطاع الخدمات من أكثر القطاعات المســاهمة في التشــيل بمعدل 61 \%، يليه قطاع البناء و الأشـال العمومية بنسبة 17\%، ثم قطاع الصــناعة بنسـبة 14 \% ، ليحتل قطاع الصــناعة المرتبة

الأخيرة بنسية 8 \%. (boulifa mihouar, 2019) الرفع من القيمة المضــافة: ظهرت مســاهمة المؤسـســات
العالم، حيث أصــبحت تشــكل ما يفوق 90 \% من النسـيج الاقتصــــادي وذلك نظر ا لمـا تتميز بـهـ هذه الأخيرة من مميزات جعلتها تحتل الصدارة ومن بين أهم الخصائص ما يلي: - صــــر الحجم الـذي يجعـل من الهيكل التنظيمي لهـذه المؤسسـات بسبطا ومرنا، و الاتصـال فعالا، ممّا يؤدي إلى لى السـر عة و الدقة و المرونة في اتخاذ القر ارات وبالتالي عدم إضـــاعة فرص الربح في الســوق، إضـــافة إلى ســــولة انتشـــار ها في مناطق عديدة وتحقيق التوازن الجهوي الذي يضــمن التوزيع العـادل للدخل، وكذا ســـهولـة دخولها وخروجها من السـوق دون أن يُخلف ذللك نتائج سـلبية على الاقتصاد. - الانخفاض النسـبي للتكاليف التأسـيسـية بها، وسـهولة در اسة الجدوى الاقتصادية لإقامتها و إعداد مخططاتها، إلى جانب قصــر الفترة اللازمة لتشـــيلها التجريبي، يعطيها فرصة حرية وسهولة اختيار النشاطو إبر از القدر ات الذاتية لمســيريها على تعبئة المدخر ات الخاصـــة. (ســليمـان و

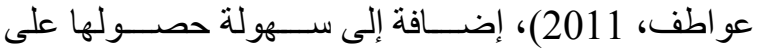
التمويل اللاّزم من طرف المالكين سو اء في شكله العيني أو النقدي، و هذا يقلل من الضـوط المالية للبنوك و المؤسسـات التمويلية الأخرى. (مباركي ، 1999)

\section{واقع المؤسسـات الصغيرة والمتوسطة في الجزائر:}

(bulletin d'information statistique de l'entreprise, 2020) اهتمت الجزائر وكغير ها من دول العالم بقطاع المؤسـسـات الصـــيرة و المتوســـة، حيث ســـرت لها الحكومة كلّ الوســـائل المـالية و التقنية للنهوض بها، اقتناعـا منها بأنّها

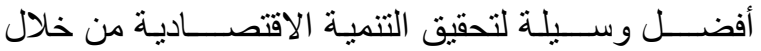
امتصــاصــها للبطالة ومســاهمتها في تحسـين المؤشـرات الاقتصـــادية الكلية ، إذ بلغ عدد المؤسـســــات الصـــيرة و المتوســطـة إلى غـايـة نهايـة ســـــة 2019 مـا يعـادل 
بالفيروس ومن ثم ملامسة العين أو الانف أو الفم. ظهر فيروس كورونا لأوّل مرة في شـهر ديسـمبر من ســنة 2019 في مدينة وو هان الصينية، حيث تتمثل أعر اضـه في الحمى و الار هاق و الســعال الجاف، وقد تصــل لدى بعض

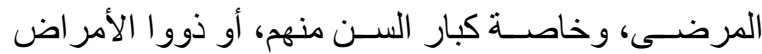
المزمنة، إلى حالات ضـيق تنفس شـديد تسـتدعي وضـعهم تحت الرعاية الطبية المسـتعجلة ووصــــهم بأجهزة التنفس الاصطناعي.

\section{فيروس كورونا في الجزائر:}

كان أوّل ظهور للفيروس في شـهر ديسمبر من سـنة 2019 في مدينة وو هان الصـينية، و انتشـر بشـــل سـريع إلى كل أنحاء العالم، حيث تم الإعلان من طرف منظمة الصــــة العالمية رســميا في 30 يناير 2020 بأنّ تفثـــي الفيروس

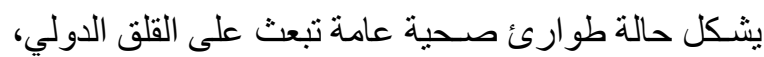
و أكدت تحول الفاثـــية إلى جائحة يوم 11 مارس من نفس

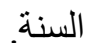

إنّ الجز ائر و على غرار باقي دول العالم اكتشــت أوّل حالة إصــــابـة بـالفيروس في 25 فبراير2020 لـدى رجـل إيطـالي الجنســــــة وصــــل إلى الجزائر في 17 فبر اير، وقامت الجز ائر بترحيله في 28 فبر اير من مطار حاســي مســود الدولي في رحلة خاصــة بعد أن تعرض للحجر الصحي حتى تللك الفترة. (ويكيبيديا، 2020) انتشــر الفيروس بثـــل سـريع في الجزائر بداية من و لاية البليدة التي طبق عليها الحجر الكلي في 23 مارس 2020 بحكم أنّها بؤرة الوبـاء، إلى أن وصـــل إلى كلّ و لايـات الجزائر، حيث وصل عدد المصـابين إلى غاية 09 ديسمبر 2020 إلى 89.416 حالة، من بينهم 58.146 حالة شـفاء، و2.539 حالة وفاة.

نتيجة لما ســـق لجأت الجزائر بفرض إجراءات احترازية صـــارمة للحد من انتشـــار الوباء، كالحجر المنزلي الكلي على الولايات التي صــنفت كبؤرة للوباء، والحجر الجزئي
الصـــغيرة و المتوســــة في القيمة المضــــافة، من خلال

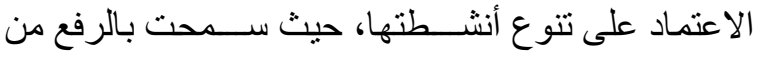
القيمة المضـافة من 10106,8 مليار دينار سـنة 2017 إلى 10886,62 سنة 2018 أب بنسبة ارتفاع 7.71 \%، حيث كانت مســاهمة القطاع الخاص في ذلك أكبر من مســاهمة

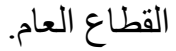
تعديل الميزان التجاري: شـــــد الميزان التجاري الخـارجي ســـــة 2019 انخفاض في الو اردات بنســــــ 9.49 \%، و انخفاض في الصـادرات بنسـبة 14.29\% و هو ما خلّف خســارة في الميز ان التجاري تعادل 6.11 \%، وذللك يعود أسـاسـا إلى اعتماد الجزائر على المبادلات التجارية الدولية في قطاع المحروقات بدرجة كبيرة جدا. 2.1. 4

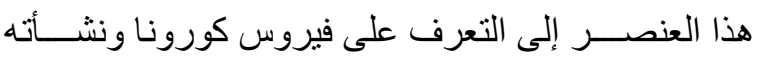
وو اقع انتقاله إلى الجزائر و انتشاره. تعريف فيروس كورونا:

يعرف فيروس كورونـا (COVID-19) بـأنّه: " فصـــيلة كبيرة من الفيروســـات التي قد تســبب المرض للإنســـان و الحيوان، إذ أنّها تسبب حالات عدوى الجهاز التنفسي التي تتر اوح ما بين نزلات البرد الثــائعة إلى الأمر اض الأثــــ

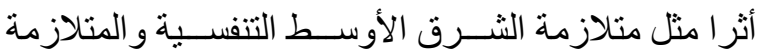
التنفسية الحادة (السارس)" (الهرش، 2020) كما يعرف بأنّه: " فيروس حاد وشديد يلازم ويصيب الجهاز التنفسـي ويكون على شـكل كريات مسـتديرة أو بيضـاوية ومتعدد الأشكال في كثير من الأحيان على مستوى الرئتان، (زيادي و بن جروة ، 2020) الذي ينتقل بشكل أساسي عن طريق الاتصــال المباثــر بالرذاذ التنفسـي الصــادر عن شـخص مصـــاب عند العطس أو الســـال، أو عن طريق الانتقــال الجوي عنـدمــا يتعرض النـاس لفترات طويلــة لتركيز ات عالية في الأماكن المغلقة نسـبيا، وقد يصـل إلى درجة الانتقال بمجرد ملامســـة أســــح أو ســـلع ملوثنة 
اجر اء مو اصـلة الدر اسـة عبر البث المباثــر للاروس عبر أجهزة التلفزيون بالنسبة للتلاميذ الخامسة ابتدائي، و الر ابعة متوســــ و الثالثة ثنانوي، و التدريس عن بعد بـاســـتخدام منصـات التعلم الرقمي عبر الانترنت بالنسبة للتعليم العالي لئي

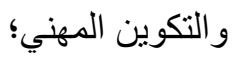

- تطبيق اجراء الحجر الصـــي، والذي كان كاملا على ولاية البليدة التي كانت عبارة عن أوّل و لاية تصنف كبؤرة وباء، وجزئيا على باقي ولايـات الوطن حســبـ معطيات الإصـابة في كلّ ولاية؛ - فرض وضـــع الكمـامـات الطبيـة في كلّ القطـاعـات و المحلات التجارية مع ضـرورة توفر المعقمات في مدخل كلّ محل أو إدارة أو مؤسـســة، مع احتر ام مبدأ التباعد بين

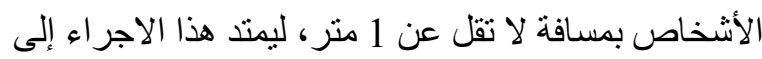

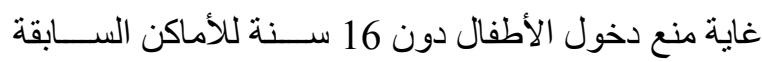

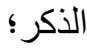

- تعليق عدّة نشـاطات اقتصـادية كالنقل بمختلف وسـائله البرية و الجوية، الحضـرية و الثـبـه حضـرية، وكذا محلات بيع المشـروبات، مؤسـســات وفضــاءات الترَّفيه و التسـلية و العروض و المطاعم، باســـتنـاء تللك التي تضــــن خدمة التوصـــيل إلى المنازل وذللك في المدن الكبرى، ليمتد فيما

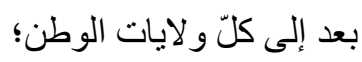

- قرار بغلق قـاعـات الحفلات والاحتفـالات و الأعر اس العائلية، وكذا الغلق الكلي للمقاهي و المطاعم و المحلات، بـاســنتثـاء محلات المواد الغــائيـة (المخـابز و الملبنـات و البقالات ومحلات الخضـــر و الفو اكـه)، حيث تحدد في قانون العقوبات تطبيق عقوبات صـــار مة على كلّ مخالف لهذه الإجر اءات تمتد من تســديد غر امة مالية إلى ســـب السجل التجاري و المنع النهائي من مزاولة النشاط؛ - وضــع 50 \% من العمال في عطل اســتنثائية مدفوعة

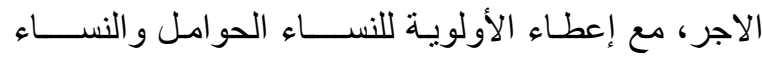
الـــكفلات بتربية أبنائهن الصغار ، وللأشخاص المصابين
على بـاقي الولايـات، تعليق الرحلات الجويـة الـداخليـة و الخارجية و العديد من الإجراءات الأخرى التي ترمي في مجملها إلى ضـــمان الســلامة الصــحية للثـــب بالدرجة

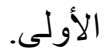
4 .2. 4 تأثير فيروس كورونا على الاقتصاد

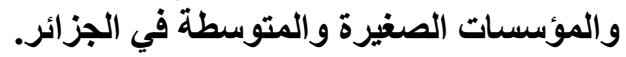

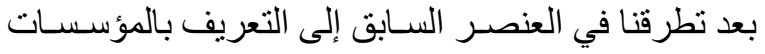
الصــغيرة و المنوســة في الجزائر وخصــائصـــها ومدى مشــاركتها في تحسـين العديد من المؤشـر ات الاقتصــادية، بـالإضــــافـة إلى إلقـاء نظرة وجيزة على فيروس كورونـا وو اقعه في الجزائر، سـوف نتطرق من خلال هذا العنصـر إلى مختلف الإجر اءات الاحتر ازيـة التي اتخذتهـا الحكومـة فئة الجزائريـة للحد من انتشــــار الوبـاء، مع القاء نظرة حول مختلف مخلّفـات هـذه الإجراءات على المســتوى الكلي و الجزئي، لنتوصل في الأخير الى استنتاج الاثار الإيجابية

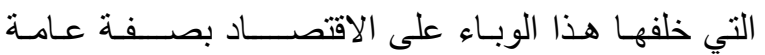
و المؤسسات الصغيرة و المتوسطة بصفة خاصة.

\subsection{4 الإجراءات الاحترازية للحد من وباء كورونا:}

ســـار عت الجزائر على غرار بـاقي دول العـالم إلى اتخـاذ التدابير اللازمة للحد من انتيــار فيروس كورونا، حيث تمّ اصدار العديد من القر ارات عن المجلس الأعلى للأمن، إلى جانب التوقيع على عدّة مر اســـيم تنفيذية، وفرض تعليمات خاصة بكلّ قطاع حسب خصوصيته.

وتتمثل أهم الإجراءات المطبقة في هذا الصدد فيما يلي: تعليف - تعليق الرحلات الجويـة بين الجزائر و المغرب ثم بين الجز ائر وفرنســــا لتمتـد فيمـا بعد إلى كلّ الرحلات الجوية

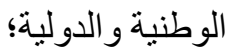
- تقديم العطلة الربيعية بالنسـبة لكلّ المسـتويات الدر اسـية بمـا في ذلك الجـامعيـة ومر اكز التكوين المهني، ومدارس التعليم القرآني، والزوايــا وأقســــام محو الأمبــة وجميع المؤسـسـات التربوية الخاصـة ورياض الأطفال، مع اتخاذ 
- - انخفاض احتياطي الصــرف من 193.6 مليار دو لار عام 2014 إلى 62 مليار دولار مع بداية سـنة 2020، ممّا يجعل الجزائر في خطر فيما يتعلق بدعم اقتصـــادها؛ (بن عودة، 2020) - - من بين أهم الإجراءات الاحترازيـة التي فرضـــتهـا الجز ائر تقييد الاستير اد، وحظر جميع صـادر ات المنتجات الغذائية الأسـاسـية المسـتهلكة على نطاق واسـع، فحسـب احصـائيات الجمارك وصـلت قيمة اسـتير اد المواد الغذائية 1.293 مليار دو لار خلال أوّل شـــرين من ســنة 2020؛

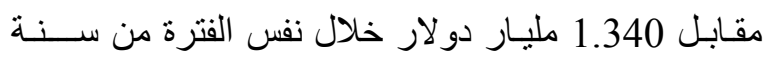
2019 ، أي أنّها شــــدت انخفاض يقدر ب 3.50 \% ممّا خفض من فاتورة الاســتير اد من (GANA, 2020)

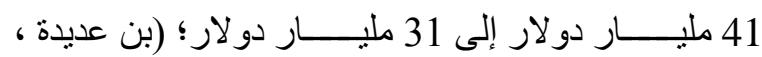
‘(2020 - ارتفـاع تكـاليف التصــــدي واحتو اء الوبـاء، من خلال تجهيز المسـتشـفيات، منح الدعم و الاعانات للفئات الأكثر تضررا، وتحمل نفقات تشـغيلية ناتجة عن العطل المدفوعة الأجر دون القدرة على الحصــــول على إير ادات لتغطيها، و هذا كلّه شـكّل ضـغطا كبير ا على ميز انية الدولة وخططها التنمويـة، حيث رفع من شـــدة الركود من 1.83 \% \% 7.87 في الســنة الأولى من الوباء؛ \& \& BENNIHI)

BOURICHE, 2020)

- نراجع المداخيل الســياحية نظر التعليق الرحلات البرية و الجويـة و البحريـة بين الجزائر وكلّ دول العـالم كـإجر اء

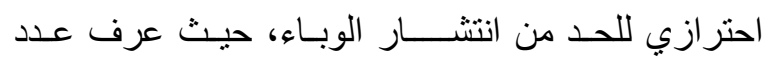
المسـافرين تر اجعا بقيمة 5.8 مليون مسـافر، ممّا أسفر عن خسـارة في الإير ادات تقدر ب 0.8 مليار دو لار ، وخسـائر تقدر ب 3.1 مليار دو لار في الدخل القومي، إضـافة إلى أنّ النّا

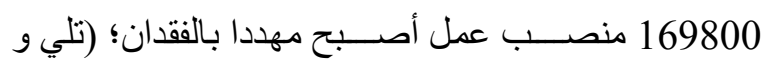

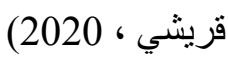

بأمر اض مزمنـة، في كامل القطاع الاقتصـــادي العمومي

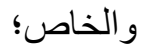

\subsection{4 الآثار السلبية لفيروس كورونـا على الاقتصاد}

\section{وانعكاساته على المؤسسات الصغيرة والمتوسطة:}

ممّا لا شك فيه أنّه بالإضـافة إلى الآثار السلبية الصحية التي نتجـت عن انتشــــار الفيروس في الجزائر، فـإنّ آثـاره الاقتصــــادية كانت وخيمة على كلّ من المســـتوى الكلي و الجزئي وفيما يلي عرض لأهم هذه الآثار. الآثار السلبية لفيروس كورونا على الاقتصاد لقد كان لفيروس كورونا تأثثير كبير على اقتصـــاديات كلّ هورت دول العالم، إلّّ أنّ تأثنيره كان أكبر على الدول النامية التي تعتبر الجزائر واحدة منها، وذللك نظر الارتكاز هذه الدول على مداخيل النفط لتمويل مشــاريعها التنموية، وتتمثل أهم

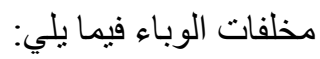
- مقدت الجزائر نصـــف مداخيلها من العملة الصـــعبة بسـبب تهاوي أسـعار النفط في الأسـواق العالمية (كرامة، رحسال، و خبيزة ، 2020)، حيث انخفضـــــ عـائدات المحروقـات ب 1 مليـار دولار في نهايـة فبراير 2020 (لعبيدي و دوش، 2020)، كما يتوقع البنلك الدولي ارتفاع العجز المـالي إلى حوالي 16.3\% من النـاتج المحلي الاجمالي الذي من الممكن أن ينكمش إلى نسبة \% 3 تماثيا مع انكماش الاســتهلاكك الخاص والاســتنمار جر اء تقييد الحركة و التجمعات (بن عودة، 2020). أنّر انخفاض أسـعار البترول على مستويات نشـاطو وموارد

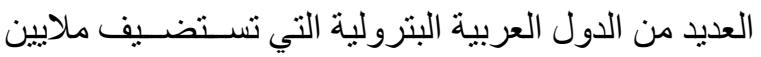

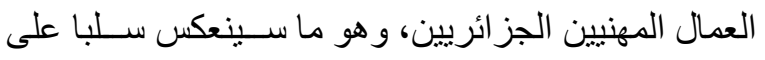
الاقتصــــاد الجزائري من خلال انخفاض تحويلات هؤلاء العاملين والتي تمثل تقريبا أكبر مصــادر الجزائر من النقد الأجنبي، واحتمـاليـة عودة قطـاع كبير منهم إلى الجزائر، وهو ما سيُفاقم من مستويات البطالة. 


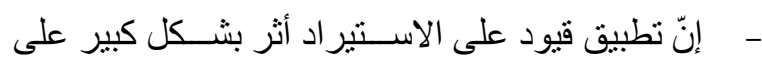
الثـركات و المؤسـســات الصــيرة و المتوســة التي كانت تعتمد على المادة الأولية المستوردة، وهو ما تسبب لها في تخفيض الإنتاج، وبالتالي الاستغناء على جزء من العمالة؛ - إنّ تغيّر سلوك المستهلك واتجاهه نحو السلع الأساسية (مو اد غذائية، معقمات، مو اد طبية) أثر بشــــل كبير على المؤسـسـات التي تعمل في قطاعات مغايرة، حيث اضــر الكثير منها إلى تخفيض حجم الإنتاج وبالتالي تسـريح جزء من العمـال، أمّا أخرى فلم تتمكن من الصـــمود في وجـهـ الازمة و أغلقت أبو ابها؛ لقد كان للإجر اءات الاحتر ازية التي اتخذتها الحكومة للحد من انتشار فيروس كورونا عدة آثار سلبية على المؤسسات الصغيرة و المتوسطة و التي سنستدرجها في النقاط التالية:

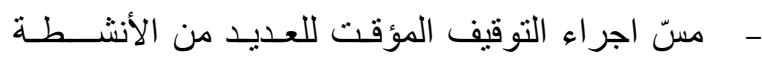
الاقتصــــادية عدّة قطاعات حيوية بثـــكل مباثـــر كالنقل المقاهي، المطاعم، قاعات الحفلات، قاعات الرياضة و التي تنتمي إلى قطاع الخدمات الذي يعتبر ثنالث قطاع رئيســي مسـاهم في تحسـين المؤشـرات الاقتصــادية كونه يوفر 60 \% من فرص العمل، و 44 \% من النـاتج الداخلي الخـام، و2.2 من القيمة المضـافة، (العبسي و تيجانية، 2020) ، حيث اضـــر أصـــاب هذه النشـــاطات إلى الاغلاق هل وبالتالي وضع عدد هائل من العمال في البطالة المؤقتة، مع إع التعرو انخفاض محسوس في المردودية؛ - - أثّر تعليق الرحلات الجويـة الدوليـة والمحلية بشــــل

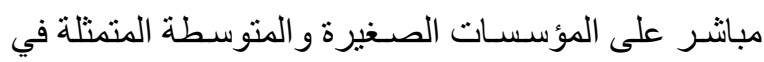
وكالات السـفر ، الفندقة، مؤسـسـات الاسـتير اد و التصـدير، و غيرها من المؤسـسـات التي شـهدت اغلاقا مؤقتا في ظل مورك الازمة؛ - يتميز الوضـــع الاقتصـــادي في ظل الفيروس بعدم اليقين، وهو ما يعتبر من بين أهم عو ائق الاستثمار وخاصة

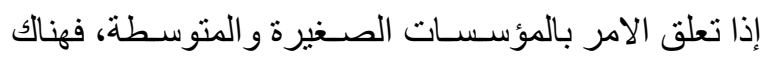

- ارتفاع حدّة البطالة بســبب التخلي الجزئي أو الكلي للعديد من المؤسـســات على عمالها، حيث نوقع صــندوق النقد الدولي ارتفاع معدل البطالة في الجزائر إلى 15.1 \% سنة 2020 بعدما قدرّ ب 11.4 \% سنة 2019 ، مع انـخـفــاض طـفـيـف ســـــة 2021 إلـى 13.9\% ؛ (BERROUCHE \& MAHDAOUI, 2020) - - تغير النمط الاســتهلاكي للأفر اد، من خلال التوجـه و التهافت على الســـع الأسـاسـية من مواد غذائية ومعقمات الصـــية، مو اد طبية، ممّا خلق ندرة للعديد من الســـلع في

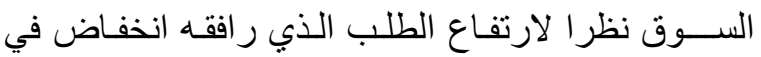

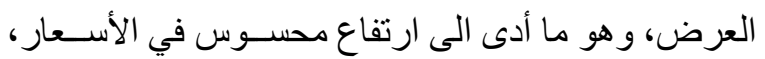
و التي حسب بيانات صادرة عن صندوق النقد الدولي سوف ترتفع إلى 3.5 \% سـة 2020 ثم إلى 3.7\% سـنة 2021،

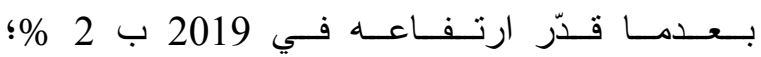
(BERROUCHE \& MAHDAOUI, 2020) الآثار السلبية لفيروس كورونا على المؤسسات

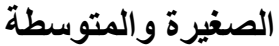
ممّا لا شـــك فيه أنّ للآثار الســلبية الســالفة الذكر لفيروس كورونا على الاقتصـاد، بالإضــافة إلى الإجر اءات الوقائية التي اتخذتها الحكومة للحد منه انعكاس ســلبي على نشــاط المؤســـــات الصـــيرة و المتوســـة، حيث تمثل انعكاس الوضع الاقتصادي على هذا النوع من المؤسسات فيما يلي: - - ســـاهم انخفاض مداخيل البترول في تـأجيل إطلاق

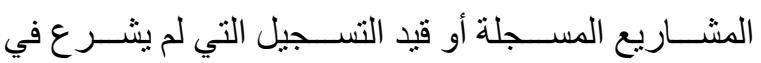
إنجاز ها ماعدا في مناطق الظل ومســتشــفى الســـرطان بالجلفة، وهو ما تسبب في إيقاف العديد من مكاتب الهندسـة

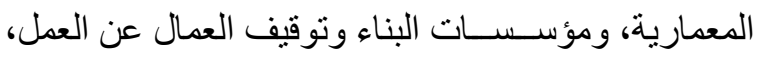
كما تســبـ انخفاض مداخيل الدولة من المحروقات من ون مضـــاعفة مشــاكل التمويل البنكي للمؤسـســات الصــغيرة

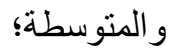


ومن بين هذه الإيجابيات ما يلي:

3.4. 1 تغيير اسـتراتيجية العمل في المؤسـســات

الصغيرة و المتوسطة

اسـتطاعت العديد من المؤسـســات الصــيرة و المتوســة خلال الازمـة من تغيير اســـر اتيجيتهـا من خلال تحويـل خطوط الإنتاج إلى الســع الأكثر طلبا في السـوق، ففي ظل ندرة المعدات الطبية لجأت بعض مؤسســات صنـع الألبسـة إلى خياطة الكمامـات الطبية و الملابس الخـاصــــة بالطـاقم الطبي، كما غيّرت مؤسسات أخرى مختصة في الصناعات الثقيلة من نشـاطها لتتخصـص في صــناعة أجهزة التنفس في لتس الاصــطناعي، و أجهزة قياس نســبة الاكســـين في الدم، و المحارير الطبية، كما ركزت مؤسـســات أخرى خاصــة بصــنـع المعقمات على انتاج المو اد الأكثر طلبا من طرف المستهلكين كماء جافيل، و الصابون السائل لليدين. لقد كانت هذه المؤسسـات من بين المؤسسـات الأكثر حضـا للبقاء والاستمر ار خلال الازمة إلى جانب مؤسسات أخرى مختصـــة في انتاج المو اد الغذائية التي شـــــت تهافتا غير مسبوق من طرف المستهلك الجز ائري، خوفا منه من ندرة هذه السلع إذا استغرقت الجائحة فترة طويلة. كانت أزمة كورونا بمثابة درس للمؤســــــات الصـــيرة و المتوسطة الجزائرية بأنّ ضمان البقاء لا يرتكز فقط على إرضـاء الزبائن وكسب ر هان المنافسة ما بين المؤسسـات، و انّما يسـتـدعي وضــع اسـتر اتيجيات بعيدة الأمد تسـتـدعي الصـمود في وجه الصدمات الغير منوقعة مهما كان نوعها

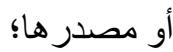

3. 4 انتعاش التجارة الاككترونية:

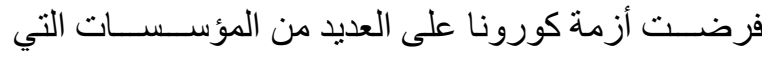
أُجبرت على توقيف نشـاطها من البحث عن سُبـل لتسـويق منتجاتها، فلجأت إلى استتعمال التجارة الالكترونية كوسيلة لذللك، حيث شــــدت مو اقع التو اصــل الاجتماعي كمّا هائلا من الإعلانات و الدعايات للعديد من المؤسســات و المتاجر ،
تر اجع ملحوظ في طلبات انشـاء مؤسسـات جديدة خوفا من

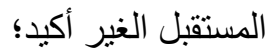
- - - أنّر قر ار غلق المؤسسـات التربوية بما فيها الجامعات ومر اكز التكوين المهني و المدارس القرآنية على العديد من المؤسسـات الصـغيرة و المتوسطة الناثـطة في هذا المجال كالمدارس الخـاصــــة، مر اكز الدعم التربوي، والمدارس القر آنية الخاصـــة، و هو ما كلفها خســائر بالغة، و أدى إلى لى تسـريح العمال بدون أجور، لفترة فاقت السبعة أثــهر، ممّا زاد من نســبـة البطـالـة وســـاءت الحسالة المـاديـة للطبقة المتوسطة و الكادحة على حد سو اء؛ - كان لإجر اء وضــع نصــف العمال في عطلة مدفوعة الأجر أثر ســلبي على مردودية المؤسـســـات الصـــيرة و المتوســة نظر ال لارتفاع تكاليف العطل المدفوعة الأجر ، ممّا أرغمها على تحمل نفقات تثـــيلية دون القدرة على الحصول على إير ادات تغطيها؛ إضـافة إلى ماسبق فلقد سـاهم هذا الإجر اء في تقليص حجم الإنتاج في المؤسسـات التي أصبحت تعمل بنصف طاقاتها الإنتاجية بها، ممّا أدى إلى انخفاض المردودية الاقتصـادية لهذا القطـاع، وبمـا أنّ هذا الاجر اء مسّ قطـاعـات أخرى الهى كالبنوك، فإنّ هذه الأخيرة أصــبحت تعمل في ظل الجائحة بعدد محدود من العمـال ممّا انعكس ســلبـا على عمليات در اســة ملفات القروض الخاصـة بالاسـتثمار و الاسـتغلال، فتوقفت كنتيجة لذلك العديد من المؤســســـات الصـــيرة و المتوسطة عن النشاط، وتأخرت أخرى عن الانثاء؛ 3 روئة استشـرافية إيجابية لاقتصساد جزائري ما

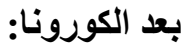
رغم الآثار الســلبية الوخيمة التي اســفرت عن انتشـــار فيروس كورونـا في الجزائر، إلاً أنّ هـذه الأزمـة ابرزت العديد من النقاط الإيجابيـة التي لا بد من الارتكاز عليها ودعمها مسـتقبلا للنهوض من جديد بالاقتصـاد الذي عرف ركودا كبير انتيجة هذه الصـــمة الصـــية الغير منوقعة، 
بالسـلع الأسـاسـية، والبنوك و البريد، و هو ما دفع الحكومة الجز ائرية لتحديد تاريخ 31 ديســمبر 2020 كبداية لنهاية الأســلوب التقليدي في الدفع و التوجه نحو اعتماد بطاقات الدفع الالكتروني لشر اء وبيع السلع في المحلات و المتاجر ، حيث يهدف قرار الحكومـة إلى نوزيع أكثر من نصــف مليون جهاز قارئ للبطاقات المـالية المغناطيســيـة على المتـاجر الكبرى أولا ثم المحلات الصـــخيرة. (علال ، (2020

شـهـ الدفع الالكتروني تطور معتبر خلال الأشـهر الأربعة الأولى من العسام الحسالي، حيـث بلغ عـدد المعـاملات 728.394 عمليـة أجريـت من قبـل مســتعملي مختلف القطـاعـات، منهـا 93.34\% ، نُفـذت فقط في قطـاع الاتصــــالات (اتصـــــالات الجز ائر وموبيليس ودجيزي

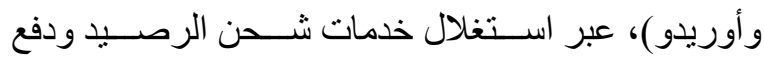
فو اتير الهاتف وخدمات الاشــتراك الداخلي. MENNA) \& MEHIBEL, 2020)

بلغت معـاملات الدفع الإلكتروني المنفذة عبر المنصــــة النقدية لبريد الجزائر المذكورة أعلاه، منذ بدء تتفيذ الحجر الصـــي في مارس الماضــي، "273 ألف عملية شـــريا" مقابل 52 ألف عملية / شـــــر في عام 2019 "، أي خمس مرات" وبلغ إجمالي المبالغ المـالية الناتجـة عن العمليات المنفذة في الأشــــر الأربعة الأولى من العام المالي 2020 أكثر من 959 مليون دينـار، ويمثنل شــــر أبريـل وحده 33.78 \% من هـا المجموع أي مـا يعـادل 324 مليون دينـار ، علمـا أنّ "الميز انيـة العموميـة للعـام المـالي 2019 بـأكملـه بلغنـات 504 مليون دينـار. \& MENNA

MEHIBEL, 2020)

إضـافة إلى ما سـبق وضـعت مؤسـســـة بريد الجزائر عدّة تطبيقات تحت تصــرف الزبائن مثل خدمة "بريدي موب" الخاص بتحويل المبالغ المـالية بصــفـة رقمية فوريـة بين حائزي الأرصــدة البريدية الجارية، و الذي حقق اسـتـغلاله
واشتدت المنافسة فيما يتعلق بطريقة عرض المنتجات عبر هذه المو اقع و اقتر اح أسـعار مغرية مع خدمة التوصيل إلى

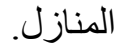
أدركت كلّ من الحكومة الجز ائرية ومؤسـسـاتها الصــيرة و المتوسـطة خلال ســنة 2020 ، وبغية مو اجهتها لفيروس كورونـا، أنّ التجـارة الالكترونيـة أصـــبحت المنفذ الوحيد للتجارة والبيع وبالتالي النجاة من الإفلاس، حيث ظهرت العديد من الصـــفـات عبر مو اقع التواصــــل الاجتمـاعي الخاصــة بعملية البيع و الثـــراء، عُرضــت فيها العديد من السلع بأسعار تنافسية، مع نوفير خدمة التوصيل إلى المنزل وضمان تبديل المنتوج في حال عدم رضا الزبون عنه، كما شـــــت هذه المو اقع تهافت كبير من طرف المو اطنين في ظل الاغلاق الثــــامـل لبعض القطـاعـات الاقتصـــــاديـة، و إجراءات الحجر الصـــي، وهو مـا كثــف عنهـ رئيس الجمعية الوطنية للتجار و الحرفيين، الحاج الطاهر بولنوار أنّ ما نســبته 40 \% من التجار ير غبون في اقتحام البيع الالكتروني ويسعون لتعلم طرقها. (هلالي ، 2020) رغم العـديـــ من الجهود الحكوميــة في مجـال التجـارة الالكترونيـة و التي تمثلت في إطلاق مشـــروع الحكومـة الالكثَرونية وتطبيق ســياســات و استَـتر اتيجيات لإنجاحه، تجهيز بنية تحتية منينة كتوفير وســـائل معلومات حديثة وشـبكة انترنت سـريعة تغطي كل أر اضــي الوطن، إلاّ أنّ مشــروع التجـارة الالكترونيـة ييقى متــأخر ا في الجزائر مقارنة بدول الجوار كتونس و المغرب، ويرجع ذلك أسـاسـا إلى انعدام وسـائل الدفع الالكًّروني و عدم اسـتخدام بطاقات دفع عالمية بالإضـافة الى انعدام الثقافة الثـر ائية عبر العالم الافتر اضي، (بوضياف و بهلولي ، 2020). 3. 3 . 3 تفعيل سياسة الدفع الاكتروني:

كثـــف وبـاء كورونـا في الجزائر العديد من العيوب في الممارسات الاقتصادية، وساهم غياب الدفع الالكتروني من انتشـــار طو ابير طويلة أمـام المحلات التجارية الخاصــــة 
للإعلانات ونقل انثــالات الطلبة أو التو اصـل عن طريق البريد المهني للأســـاتذة و الطلبة، أو بـالفيديو بعد تحميل تطبيقات مجانية مثل: GOOM و GOOGLE MEET ، حيث تمّ في هذا الصـــدد ابر ام اتفاق وز ارة التعليم العالي و متعاملي الهاتف النقال و الثابت لتســــيل ولوج الطلبة إلى المنصــة التعليمية الخاصــة بالمؤسـســة التي ينتمون إليها مجانا، وفي نفس الســياق فتح الديوان الوطني للمطبو عات $\ddot{a}$

قاعدة بيانـاتـه الرقميـة للتحميل المباشـــر بـالمجـان، (بن رجدال، 2020) كما تمّ تنظيم العديد من التظاهر ات العلمية الافتر اضـية من مؤتمر ات وملتقيات دولية ووطنية من قبل العديد من الجامعات الجز ائرية و التي شــــــت الأســـاتذة و الباحثين على الاستمر ار في البحث العلمي وتدعيمه.

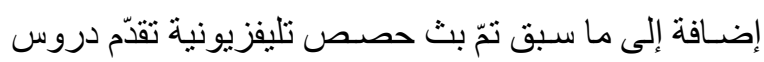
لتلاميذ الســة الخامسـة ابتدائي، و الر ابعة متوسـط، و الثالثة ثانوي، وتمّ تفعيل الرقمنة في المؤسـسـات التربوية بشــكل يســح للأولياء بسـحب كثــوف نقاط أولادهم المتمدرسـين

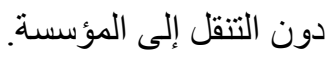

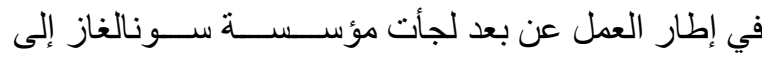
السماح لموظفيها بمو اصلة عملهم الاداري بو اسطة الوسائل التكنولوجية الحديثة التي تسـمح بالتحاضـر و الاجتماع عن بعد. (بن رجدال، 2020) إلاّ أنّه في غياب إطار تتظيمي لكيفية ممارســـة العمل عن بعد في الجزائر أثثرت العديد من الإشــكاليات، حالت دون التوسع في تطبيقه بشكل كبير . (بلميهوب ، 2020) 3. 4 5 العقلانية في استغلال الموارد:

ربما قد تكون جائحة كورونـا درس تســتفيد منه الحكومة و المؤسـســات و الثــعب كافة في التخلص من الممارسـات السـيئة كالاســتهلاك الغير عقلاني، والاســتعمال المفرط للموارد و الثروات الطبيعية، حيث نجد أنّ المستهلك أصبح عقلانيا في قر ارات الشر اء بترتيبه للأولويات الاستهلاكية،
خلال الخمس أشـهر الأولى من سنة 2020 قفزة نوعية بما يفوق 234ألف عملية، ســـلت مبلغا قياســيا قدر ب 3.2 مليار دينار جز ائري متجاوزة بذللك تحويلات ســنة 2019 التي وصـلت في مجملها خلال الســنة كاملة 2 مليار دينار جز ائري، إضـــافة إلى خدمة جديدة للاففع عبر تطبيق على الهاتف المحمول إســها بريد باي " barid bay" لتســيل عمليات الدفع. (وكالة الانباء الجزائرية، 2020) رغم الاحصـائيات الايجابية السـابقة الذكر، إلاّ أنّ سـياســة رلهـ الدفع الالكتروني في الجزائر ماز الت ضــــعيفة مقارنة بما تستدعيه التطور ات العالمية الحديثة، إذ لا بد لها أن تتوسع لتشمل قطاعات أخرى غير الاتصالات.

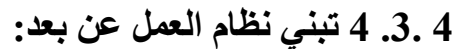

بعد اتخاد الجز ائر قر ار غلق نطام المؤسـســــات التربوية بما في ذللك الجامعات ومر اكز التكوين المهني، وكذا وضع 50 \% من العمال في عطلة استثنائية مدفو عة الأجر ، أصبح لز اما عليها أن تبحث عن طريقة جديدة لتنفيذ علاقة العمل، حيث لجـأت في ذللك إلى أســلـوب العمـل عن بعد في المرافق العمومية من خلال اصـدار المرسـوم التنفيذي رقم 20-69

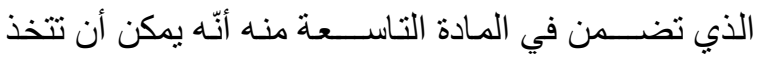
المؤسـســات والإدار ات العمومية إجر اء العمل عن بعد في ظل احتر ام القوانين و التنظيمات المعمول بها. (المرســوم التنفيذي 20-69، 2020) كانت الجامعات والمعاهد الجزائريـة أوّل من اعتمد هذا النمط من العمل من خلال توجيـه تعليمـة من وزير التعليم العـالي رقم 2020/288 مؤرخـة في 29 فيفري 2020 و التي دعى من خلالهـا إلى ضـــرورة وضـــع الـدعـائم

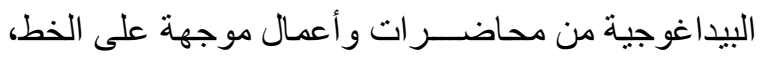
وتحسيس الطلبة والأساتذة للانخر اط في هذه العملية. كما تمّ تفعيل منصـة تعليمية رقمية MOODLE في موقع كل جامعة، و التي يمكن من خلالها تحمبل المحاضـــرات و المشـــاركة في الاعمـال الموجهة، مع تخصـــــ جزء 
لقد كانت أزمة كورونا بمثابة درس للمؤسـسـات الجزائرية بأنّ مسؤوليتها لا تقتصر فقط على الإنتاج وتقديم الخدمات بهدف إرضـــاء الزبائن وتحقيق الأرباح، و إنّما تتعدى ذلك لتشمل المجتمع الذي تنشط فيه فهي جزء لا يتجز أ منه، كما أدركت المؤسـســــات في ظل الأزمـة أنّ مســـؤوليتهـا الاجتماعية اتجاه المجتمع لا تعتبر تكاليف إضـــافية تتقل كاهلها فحسـب، بل إنّها مشـاركة في المجتمع تُكسـبها هيبة ومكانة عالية بين العملاء، وتحسّــن ســمعتها، إذ أنّها تعتبر أحد مؤشر ات نجاح الشركات.

\section{7 . 7 الارتكاز على نموذج التنوع الاقتصادي:}

إنّ الخسائر البالغة التي تكبدتها الجزائر خلال أزمة كورونا تعود أســاســا إلى اعتمادها المفرط في تمويل مشــاريعها التتموية ومعالجة الاختلالات على مداخيل المحروقات التي شـهدت انخفاضـا بالغا جر اء الاغلاق الثـامل للاول وتوقف النشـــاط الاقتصـــادي بها، و هو ما يعتبر في الوقت الحالي بمثنابـة فرصــــة حقيقية من أجل إعـادة النظر في نموذج اقتصـادي جديد يرتكز على التنوع الاقتصـادي خارج قطاع المحروقةات، لضــــــان تنوع مصــــادر الـخل، وحمـايـة الاقتصـــاد الوطني من التبعية النفطية و العيش بكر امة. (بن عديدة ، 2020) كـالاســتثــار في الطـاقـات المتجددة، ، (guembour \& raki, 2020)... الزر اعة، السـياحة ممّا سيسمح بتحقيق الاكتفاء الذاتي خاصة في مجالي الغذاء و الصـــــة ســــو اء بالاهتمـام بالكو ادر البشـــرية أوتطوير الصــناعات الدوائية و الغذائية (الهرش، 2020)، من جهة و إعطاء فرصـة جديدة للمؤسـسـات الصـغيرة و المتوسـطة للمســـاهمة في تتمية قطاعات اســتر اتيجية و اثبات دور ها الفعلي في تنمية الاقتصاد. في هذا الصـدد أثشـار رئيس المجلس الوطني الاستشتساري للمؤسـسـات الصــيرة و المتوســة أنّ بلوغ هدف مليوني مؤسـســة صــيرة ومتوسـطة في حدود سـنـة 2025 يكون شـريطة وضـع اسـتر اتيجية صـنـاعية حقيقية و الخروج من
كما تســى المؤسـسـات في الوقت الحالي إلى العمل بالحد

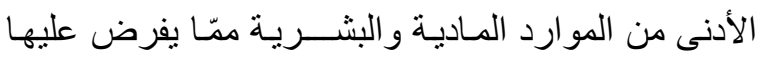
الحكمة في اســتغلال هذه الموارد من أجل البقاء في ظل الازمة وما بعدها.

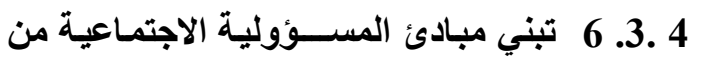

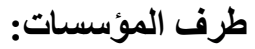
مع ظهور وبـاء كورونـا أصــبح القطـاع الخـاص في تحدّ مباشر مع الأزمة، حيث فُرضت عليه وليه العديد من الإجر اءات الوقائية، من بينها ضــرورة المحافظة على صـــة العمال من خلال توفير المعقـات، وأجهزة قياس الحرارة يوميا، مع التعقيم الدوري لأماكن العمل. إضـافة إلى ما سبق جسّدت العديد من المؤسسـات الصغيرة و المتوســطة في الجزائر مسـؤوليتها اتجاه المجتمع، حيث شـاركت العديد منها في حملات تنظيف الثـو ارع و الأماكن العموميـة من خلال توفير المعـدات اللازمـة للذلك، كمـا ساهمت بعض المؤسسات في خياطة كمامات طبية مجانية أو بسـعر مخفض لســـ النقص الذي شـهده العرض في هذا المجال، حيث قامت شـركة 》 MAPAP «التابعة للمجمع العمومي للنســيج و الجلود بتحويـل نشــــاطهـا إلى انتـاج الكمامات، كما قامت مؤسسـات أخرى بالتبر ع بمبالغ مالية للمسـتشـفيات، على غرار مؤسـســة دجيزي التي تبر عت بمبلغ 42 مليون دينار جز ائري خُصسّـص لثــر اء المعدات الخاصـة بالمستنـفيات، إضـافة إلى قيام بعض المؤسســات بالتبرع بتجهيز ات طبية كما فعلت شركة "مدار هو لدينغ" و المؤسـســــة الوطنية للصـــناعـات الالكترونيـة ENIE. (صديقي، عبد الدائم، و عبد الكريم ، 2020) في إطار المسؤولية الاجتماعية قامت العديد من مؤسسـات الاتصـــال بإنتاج ومضــات تلفزيونية تحسـيسـية موجهة للجمهور، و ارسـال رسـائل نصية في الهواتف النقالة تدعوا إلى ضرورة التقيد بالإجر اءات الاحتر ازية للحد من انتشار الوباء مثلما هو الحال في مؤسسة أوريدو وموبيليس. 
أدركت المؤسسـات الصـغيرة و المتوسطة مدى أهمية إعداد اســتر اتيجية بعيدة الأمد تجعلها أكثر مرونة وتضـــمن لها البقاء و الاســتمر ار في حالة حدوث تغير ات أو صـــدمات

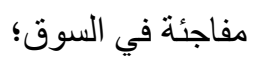

أدركت المؤسـســات الصــيرة و المتوســـة مدى نجاعة أسـلوب التجارة الالكترونية في تسـويق منتجاتها وكسـبـ

$$
\text { زبائن جدد، وتحقيق المردودية؛ }
$$

تمّ تفعيل سـياسـة الدفع الالكتروني ممّا سـيوفر جهدا كبير ا من طرف الزبون من جهة ومختلف الإدار ات والمؤسسات المتعامل معها من جهة أخرى، إلّ أنّ هذا النظام مـاز ال يحتـاج إلى تطوير أكثر حيـث اقتصـــر فقط على مجـال الاتصالات، و الذي استحوذ على 90.34 \% ، بينما ما زال التوجه نحو اعتماد بطاقات الدفع الالكتروني لشـــراء وبيع السلع في المحلات و المتاجر ضعيفا وغير مفعلا؛ تمّ تفعيل نظام الرقمنة، و الدر اســـة عن بعد و العمل عن بعد وذللك بغية حماية مناصـــب العمل من الضـــاع و الحفاض على المؤسسـات، واستكمال السنة الدر اسية الجامعية التي تسـتـدعي در اســة ســـاسـيين كاملين، إلاً أنّ الو اقع الميداني يبين أنّ العمل عن بعد في الجزائر يمـارس بصــفـة غير منظمة قانونا، إذ يقتضي ذلك استحداث استير اتيجية وطنية

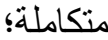
أدركت الحكومة و المؤسـســات و الثــــب كافة أنّ المو ارد مهما كان نو عها وحجمها فهي قابلة للنفاذ، لذللك لا بد عليها من التخلص من الممارســات السـيـئة كالاســتهلاك الغير عقلاني، والاستعمال المفرط للمو ارد والثروات الطبيعية؛ اتجهت العديد من المؤسـســات الخاصــة نحو المسـؤولية الاجتمـاعيـة من خلال المشــــاركـة في حملات تطو عيـة وخيرية للتصـــدي للوباء، إلاّ أنّ هذا الاتجاه ماز ال يعتبر مجرد تكتيلك تلجأ له المؤسـســات في ظروف ومناســبات معينة، و لا يعتبر منهاج عمل ممارس ضـــمن إطار خطط

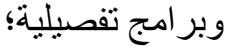

دو امة الاستير اد الذي يُميّز الاقتصاد الوطني.

$$
\text { 9. - 9 }
$$

تعتبر جائحة كورونا بمثابة صدمة قوية انعكست سلبا على كلّ المجالات الصـحية والنفسية و الاجتماعية و الاقتصـادية

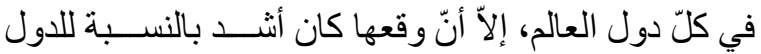
النامية وخاصة تلك الدول التي لطالما اعتمدت على مداخيل المحروقات في تمويل مشــــاريعها التنموية وموازنة ميزان المدفو عات على غرار الجزائر. فرضــت أزمة كورونـا على الجز ائر من اتخاذ عدة قرارات من شـأنها التصــدي و الحد من انتشـار الوباء بغية الحفاض كرن على السلامة الصحية للمو اطنين كإلغاء أو توقيف أو تأجيل العديد من النشاطات الاقتصـادية و الاجتماعية و الثقافية التي تستدعي الاتصـال الجسدي المباشـر بين الافر اد، وفي نفس الوقـت كـان لزامـا عليهـا البحـث عن طرق لمعـالجـة الاختلالات و الســلبيات الناتجة عن تلك القرارات كتجهيز المســتشــفيات، دعم العمال المحالين إلى البطالة المؤقتة،

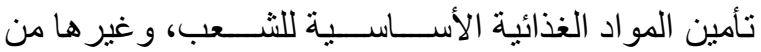
الإجر اءات التي تفرض عليها اتخاذ قرار ات اســتر اتيجية هامة للخروج من الأزمة بأقل أضر ار ممكنة. رغم النتائج السـلبية التي أسفرت عنها جائحة كورونا على لـ جميع الأصعدة الاقتصـادية و الصحية و الاجتماعية، إلاّ أنّها ســـاهمت بثـــكل كبير في تغيير العديد من الســلوكيات و القرارات الحكومية والمؤسسـاتية وحتى الثـعبية، وكانت بمثابة نقطة انطلاقة فحلية للعديد من المشاريع التنموية التي

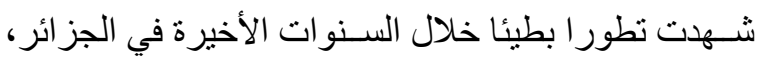
و هو ما اعتبرناه في دراستنا هذه كرؤية استشر افية إيجابية لاقتصـاد فعال ما بعد الكورونا، حيث تتمثل أهم الإيجابيات

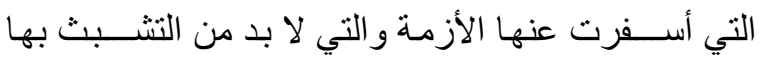
ودعمها ما بعد الازمة لخلق اقتصاد جديد فيما يلي: 
المؤســســــات تحفيزا لهم حتى يتم ادر اج المســـؤوليـة

الاجتماعية في إطار الخطط و البر امج التنموية للمؤسسة؛

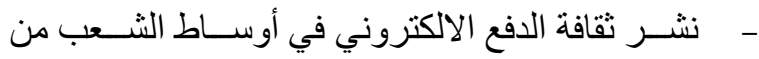

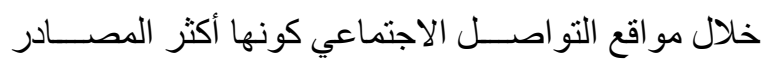
تأثثير ا على المستهلك الجزائري، و إيجاد سُبل لرفع الثقة في

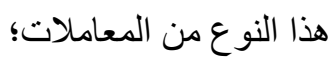

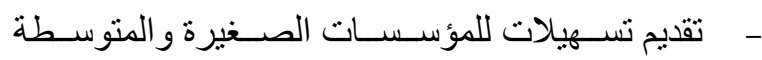

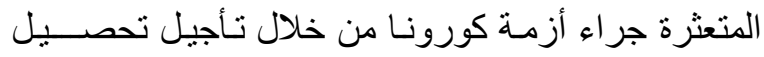
المســتحقات المالية للبنوك و الاعفاء الجزئي أو الكلي من تســديد الفو ائد، تقديم إعفاءات وتخفيضــــات جبائية، منح تعويضـات من الضـمان الاجتماعي للعمال الموقوفين مؤقتا عن العمل، مع ضـرورة تشــيع التنوع الصــناعي في هذا النوع من المؤسـســات، ودفعها للعمل في قطاعات حيوية كالزر اعة، الطاقات المتجددة، الصناعات المصنعة لضمان الامن الغذائي و التخلص من التبعية النفطية.

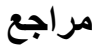

BENNIHI, A., \& BOURICHE, L. ASSESSMENT OF THE IMPACT OF COVID-19 PANDEMIC ON THE ALGERIAN ECONOMY: THE IMPORTANCE OF THE INFORMAL ECONOMY. Les

Cahiers du Cread, 36(03), 2020. BERROUCHE, Z., \& MAHDAOUI, $\mathrm{H}$, impacts de la crise sanitaire due au corona virus sur l'économie mondiale et nationale. journal of economics and management, 20(spécial), Septembre 2020.
أدركت الجزائر أنّ اعتمـادهـا على قطـاع المحروقـات لتمويل المشـــاريع التنموية، ومعالجة الاختلالات لا يعتبر حلا، لذلك لا بد لها من السعي نحو تكثيف التنوع الصناعي لمؤسـسـاتها الاقتصــادية، لضـــان تتوع مصــادر الدخل، وحماية الاقتصـــاد الوطني من التبعيـة النفطية، من خلال التركيز على الإنتـاج الغذائي لتوفير مخزون كـافي لعدة أثهر أو سنوات، وبالتالي تحقيق الامن الغذائي

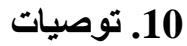

من خلال النتائج الســابقة الذكر يمكننا أن نقول أنّ الازمة الصـــحية التي و اجهتها الجزائر كانت بمثابة نقطة انطلاق للعديد من البرامج و السـباســات التي لطالما عرفت تطور ا ضعيفا خلال السنوات الماضية، رغم المجهودات الحكومية

$$
\text { التي كانت تسعى إلى تنميتها ونطوير ها. }
$$

رغم التطور الملحوظ الذي أسـفرت عنه أزمة كورونا فيما يتعلق بـالتجارة الالكترونيـة، الدفع الالكتروني، التعليم عن بعد، المســؤولية الاجتماعية، إلّّ أنّ هذه المجالات ماز الت لم تصـل إلى المسـتوى المطلوب منها المو اكب للتطورات العـالمية الحديثة، لذلك لا بد للجز ائر من دعم أكبر لهذه المجالات لضــمان اقتصــاد أفضـل ما بعد الكورونا، ولذلك نقدم فيما يلي بعض التوصيات التي قد تساهم في ذللك:

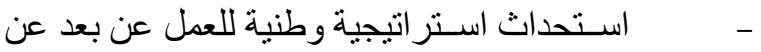
طريق تقنينه بشكل يسـح بضمان حقوق الأفر اد من ترقية و الضـمان الصـي و الذي طالما ارتبط بالعمل الحضوري، بالإضـافة إلى ضرورة تهيئة بيئة رقمية داخل المؤسسـات، ونشـر الثقافة الالكترونية في وسط العمال و المسيرين، مع توفير التكوين و التدريب اللازم فيمـا يتعلق بتقنيات العمل عن بعد وتجنب سلبياته؛ - ضـرورة مو اصــلة المؤسـسـات لأنشــة المسؤولية الاجتماعية ما بعد الكورونا مع نشـر تجاربهم في أوســاط 
, 01. ${ }^{\circ}$ Economiques, Vol. $22, \mathrm{~N}$ ‘(01)22 ،Année 2020

MENNA, K., \& MEHIBEL, S. LA •

CRISE COVID-19 AMORCE-T-

ELLE UNE NOUVELLE

TENTATIVE DE REFORMES

ECONOMIQUES EN ALGERIE. Les

Cahiers du Cread, 36(3), 2020.

أحمد فارس الهرش، أزمة الاغلاق الكبير : الآثار

الاقتصادية لفيروس كورونا كوفيد-19. مجلة بحوث الادارةو الاقتصاد، 2(2)، 2020.

" الجريدة الرسمية العدد 77، القانون التوجيهي الترقية المؤسسات الصغيرة و المتوسطة. المرسوم التثريعي رقم 18/01 المؤرخ

في:2001/12/12(77)، الجزائر، 15 سبتمبر .2001

المرسوم التنفيذي 20-69، تدابير الوقاية من وباء

فيروس كورونا كوفيد -19 ومكافحته. الجريدة الرسمية العدد 15، 5(3)، الجزائر، 21 مارس .2020

النعاس صديقي، هاجر عبد الدائم، و نادية عبد الكريم ، المسؤولية الاجتماعية تو جه حديث لمو اجهة أزمة كوفيد 19 - حالة بعض المؤسسات

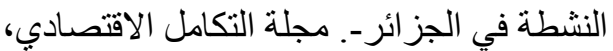
8(3)، الجز ائر ، سبتمبر 2020.

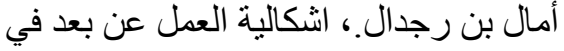
التنريع الجز ائري كنمط حديث لتنظيم العمل خلال جائحة كوفيد-19. Les Cahiers du Cread 36(3)، الجز ائر 2020. boulifa mihouar, y, Le financement des PME en Algérie état des lieux et الملتقى الوطني حول :المؤسسات perspectives. الصغيرة و المنوسطة في ظل مستجدات القانون الجز ائري -يوم 28نوفمبر 2019 جامعة تيزي وزو ,تيزي وزو ـالجزائر، 2019..

bulletin d'information statistique de l'entreprise, donné de l'année 2019. algerie: Ministère de l'Industrie et des Mines,2019. GANA, b, COVID-19 ET ÉVOLUTION DES IMPORTATIONS DES PRODUITS ALIMENTAIRES EN ALGÉRIE : IMPACTS ET PERSPECTIVES. Les Cahiers du Cread, 36(3), 2020. guembour, a., \& raki, n, The impact of coronavirus (Covid-19) on world's economy - Algeria study case-. Economic and Management Research Journal, 14(3), 2020. KIROUANI, L, la pandémie de COVID-19 et les pme. journal of economics and management, 20(spécial), septembre2020. Ouassila Leila LERARI , Impact du Covid 19 et ..HAMDAOUI management pour les PME algériennes Cas de quelques PME de la wilaya de Revue des Etudes .Guelma 
المستدامة إبان تفشي الاوبئة تحت شعار تحديات الحاضر و آفاق المستقبل. برلين، المانيا: المركز الديموقر اطي العربي للار اسات الاستر اتيجية و السياسية و الاقتصادية، مروة كر امة، فاطمة رحال، و انفال حدة خبيزة، تأثثير الأزمات الصحية العالمية على الاقتصاد العالمي: تأثير فيروس كورونا كوفيد-19 على الهى الاقتصاد الجز ائري أنموذجا. مجلة التمكين الاجتماعي، 2(2)، الجزائر، جوان 2020. ناصر سليمان ، و محسن عو اطف، الاقتصاد الإسلامي، الو اقع و رهانات المستقبل. تمويل المؤسسات الصغيرة و المتوسطة بالصيخ المصرفية الإسلامية، 06. غردايةـ الجزائر، 24/23 أفريل 2011. نبيل بن عديدة، ـ انعكاسات جائحة كورونا (كوفيد -19 ) على نشاط المؤسسات الصغيرة و المتوسطة، مجلة قانون العمل و التشغيل، 5(2) )، أوت 2020. وكالة الانباء الجز ائرية، قفزة نوعية في مؤشرات الدفع الالكتروني خلال السنة الجارية نز امنا مع تفشي وياء كورونا، 16 جوان 2020، تاريخ الاسترداد 07 ديسمبر, 2020، من وكالة الانباء الجزائرية: Www.aps.dz وليد زيادي ، و حكيم بن جروة، تقييم أداء الخدمات العمومية في ظل وباء كورونا المستجد (كوفيد 19) حالة بريد الجزائر -وحدة ورقلة. مجلة التمكين الاجتماعي، 2(2)، الجزائر، 2020. ويكيييديا، جائحة فيروس كورونا في الجزائر، مبر 09 نوفمبر 2020، تاريخ الاسترداد 22 نوفمبر, 2020؛
حليمة هلالي، البيع الالكتروني ينتشش في زمن الكورونا، 10 ماي 2020، تاريخ الاسترداد 7 ديسمبر , 2020؛ من البلاد: http://m.elbilad.net سامية بوضياف، و فيصل بهلولي، و اقع التجارة الالكترونية في الجزائر - در اسة مقارنة مع تونس و المغرب-. مجلة الأبحاث الاقتصادية، 15(2)، .2020 عبد الناصر بلميهوب،. حول إمكانية انسحاب العامل من مكان العمل بسبب فيروس كوفيد - 19. مجلة قانون العمل و التشغيل، 5(2)، الجز ائر ، .2020 علي العبسي ، و حمزة تيجانية، تداعيات فيروس كورونا كوفيد-19: الآثار الاجتماعية والاقتصادبة وأهم التدابير المتخدة للحد من الجائجة في الجزائر. مجلة العلوم الاقتصادية و علوم التسيير، 20(خاص)، 2020. محمد اسلام تلي ، و حليمة السعدية قريشي، أثر جائحة فيروس كورونا COVID - 19 على السياحة العربية البينية. مجلـة أفـــــــاق للبحوث و الدر اســات، 03(02)، الجزائر 2020. محمد الهادي مباركي، المؤسسة الصغيرة، المفهوم و الدور المرتقب. مجلة العلوم الاقتصادية(11)، الجزائر، 1999. محمد علال، الجز ائر تتجه للدفع الالكتروني لمو اكبة العالم المالي، 31 أوت 2020، تاريخ الاسترداد 07 ديسمبر, 2020، من سكاب نيوز عربية: Www.skynewsarabia.com مر اد لعبيدي، و الهادي دوش، وقائع المؤتمر الدولي الافتر اضي المسؤولية الاجتماعية للمؤسسات الاقتصادية كالية لتحقيق التنمية 


$$
\begin{aligned}
& \text { • يوسف بن عودة، انعكاسات فيروس كوفيد-19 } \\
& \text { على الاقتصاد و العمالة في العالم. مجلة قانون } \\
& \text { العمل و التشغيل، أوت } 2020 .
\end{aligned}
$$

